\title{
沖縄本島の茶園土㙴の理化学性
}

\author{
農林水産省茶業試験場
}

池ケ谷賢次郎・簿瀬 好 充

\section{On the Okinawa Island Tea Soil}

\section{By kenjiro IKEgAYA and Yoshimitsu YANESE}

\section{Natinal Research Institute of Tea}

\section{1 はしがき}

沖縄本島の土壤については，松坂ら 执よび小林らによ って詳細に調查されているが，茶園土㙲についての調查 は全く行われていないのて，昭和 49年3月4日〜 7 日ま ての 4 日間にわたり，別扏研究「農林漁業における環境 保全的技術に関する総合研究」の一環として沖綽本舅の 茶園土塞調查を行った。これらの結果が今後の沖䋥県に 扣ける茶園土潩改良の基礎資料になることを期待し，こ こにまとめて報告する。

\section{2 調查および実験方法}

まず，沖縄本皂の地兵の概要を調べるとともに，沖緡 本島全域にわたって代表的な茶園を摘出 $\mathrm{L}$, 土壤断面調 查を行った。また，士壤断面調查時に採取した層位別土 壌の粒径組成および一般化学的性質について調べた。こ れらの調査, 分析はいずれる常法に従って行った。

\section{3 調査結果および考察}

\section{3-1 沖䋲本島の地質母材別土㗒区分およひ調查茶 園の概要}

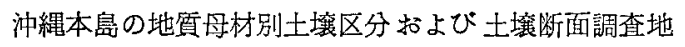
点を示すと, 図1のとおりである。

すなわち，沖縄県地質土性図によれば，沖組本島の土 䇎は古生代の粘板岩括よび石网岩，第三紀の砂岩と泥灰 岩，洪積世の国頭磁層，沖積世の海成沖積層之珊瑚石灭 岩怙よび変成岩に由来する8㮔の土篝に大別されてい る。この5 ち茶の栽培されているのは，酸性を示す国頭 碗層, 粘板岩, 海成沖積層および変成岩に由来する 4 種 の土壌地帯であった。

次に調査茶園の概要を地質母材別に区分してみると, 表 1 のと括りである。

これによると, 調查茶園の大部分にゆたかみどりが栽
培されていた。国頭嘫層および粘板岩に由来する土㙵地 带ては，物理性も比較的良好で，園相るほほ良好であっ た。1976年の沖綶県の調查によると，品種園のうち50.6

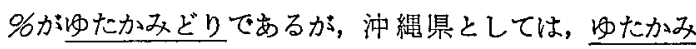
ぞりの栽培はきわめて容易で, 耐病虫性が強く, 生育, 収量とるに優れているが，芽の熟度の差がひどく，製茶 品質に悪い影響を与えるので,これらが改良された品種 の選抜を急いでいる。むた，今後の茶園造成予定地およ び既に開留が開始されていた名護市西方の海成沖積地帯 では,ガリエロージョンが強く，さらに土地崩かいが起 っているところもみられたので，新植，改植に当っては 十分な配慮が必要であろう。

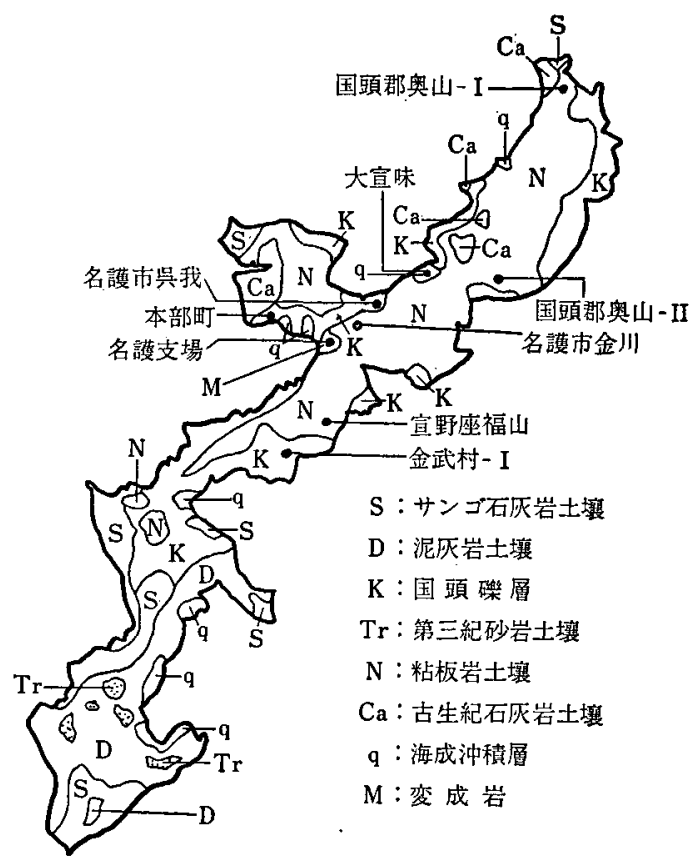

図 1 沖縄本島の地質別土壌分類拉よび諰查地点

$\dagger$ 沖縄県農林水産部農産課：沖綶県・地質土性図 (1973.3)。 


\section{3-2 土垻断面調查結果}

まず，粘板岩に由来する茶園土壤の断面状態について みると，因2のと括りである。

(1) 国頭郡奥山一Iの土境は，淡黄褐色をした埴壤土〜 軽埴土であるが，松报の分類によれば，褐色低地土に 区分されている。深さ $35 \mathrm{~cm}$ 以下は粘板岩半風化層で やや過湿状態であった。土色か淡黄色を呈しているの は，下層の過湿状態が第 1 ，第 2 層にまで影響してい るすのと思われた。徉って細根す深さ $35 \mathrm{~cm}$ までて多 く、それより下層にはきわめて少なかった。

(2) 国頭郡奥山一I，宜野座福山の両土壤は，赤褐色を 呈する土㙴であったが，松坂によれば，赤黄色土に区 分されている。国頭郡奥山一II土土垶の主な母材は粘 板岩であるが，半風化の変成岩角砅が混入していた。
この茶園も深さ $38 \mathrm{~cm}$ 以下はち密度が 20〜25を示し, きわめて硬く，細根は殆んどみとめられなかった。宜

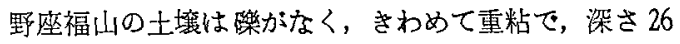
$\mathrm{cm}$ 以下ではち密度が 23 を示し, きわ力て硬く, 細根 もきわめて少なかった。しかし，この茶園は表1に示 したごとく，園相は良好であった。

(3) 名謢市金川の土壤は，黄褐色土に区分され，粘板岩 の半風化，小・中・大角際が多く含まれていたが，第 1 層以下のち密度が 22 25を示し, きわめて硬く, 細 根も少なかった。

次に国頭阻風に由来する茶園土塆の断面調査結果は,

四 3 の拈りである。

(1) 名護市䞦我の土壤は, 全層 赤褐色を呈しており, 赤 色土に区分されている。土層全体に半風化の細・小円

表 1 調 查茶 園の概要

\begin{tabular}{|c|c|c|}
\hline 地 & 地 & 概 \\
\hline 粘 & $\begin{array}{l}\text { 国頭郡奥山一I } \\
\text { 同 } \quad \text { 上一II } \\
\text { 名護市金川 } \\
\text { 宜野座福山 }\end{array}$ & 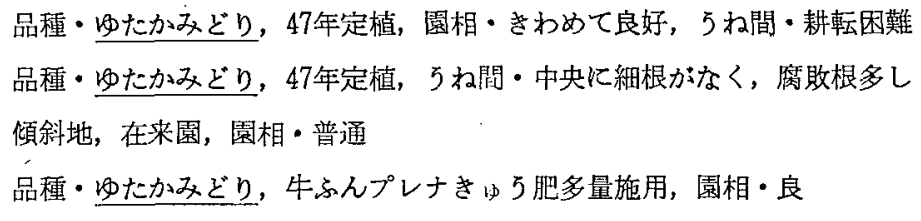 \\
\hline 国 頭 磹 層 & $\begin{array}{l}\text { 名護市呉我 } \\
\text { 国頭郡本部町 } \\
\text { 金 武 村 }\end{array}$ & 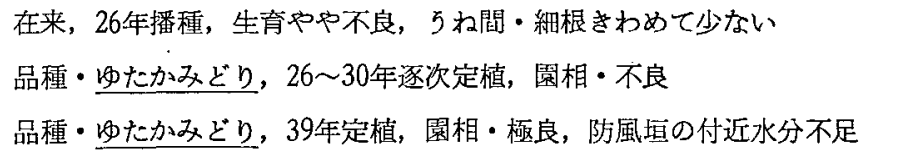 \\
\hline 海成沖積 層 & 大宜味津波 & 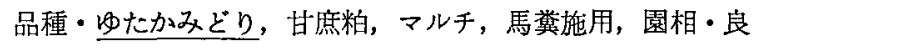 \\
\hline 変 成 & 名護 市 & 品種・ゆたかみどり, 名護支場試験園 \\
\hline
\end{tabular}

礫ち粘根

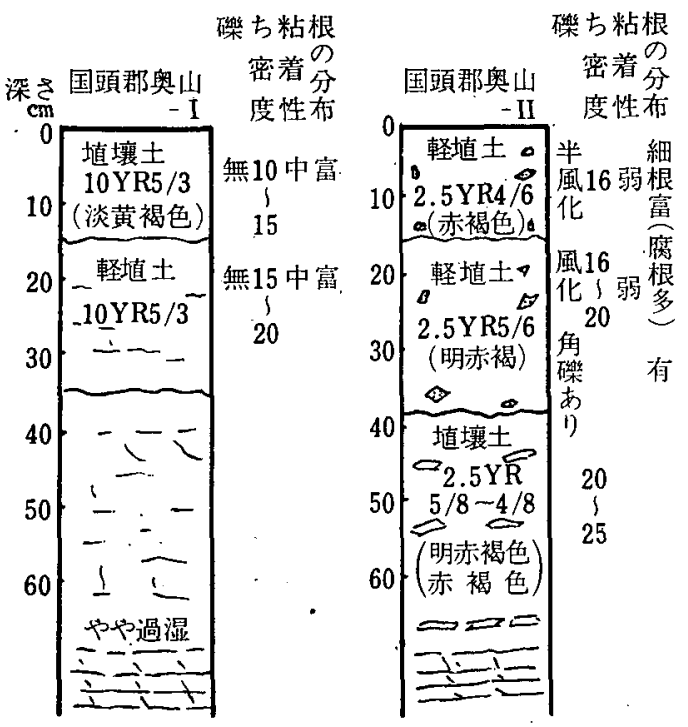

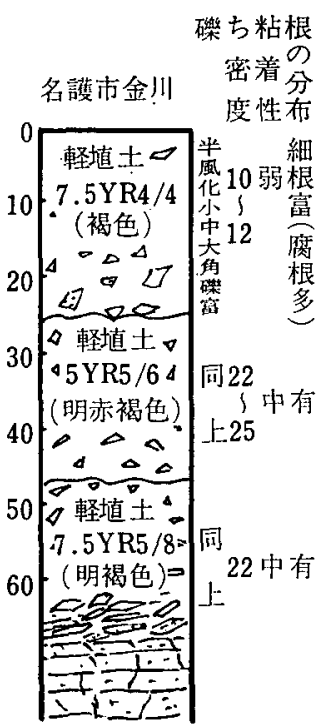

樂ち粘根

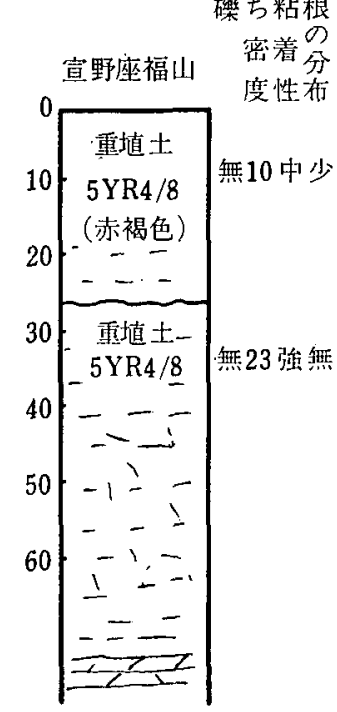

図 2 粘板岩に由来する茶園の土壤断面調査結果 
缐が含まれて扣り，比較的物理性は良好と思われた が，園相はやや不良であった。

(2) 本部町の土垬は，褐色低地土に区分され，半風化の 円棌拉よび刍砅が富み，深さ $20 \sim 38 \mathrm{~cm}$ まではち密度 が20〜24を示し，細根の侵入をさまたげていた。深さ $38 \mathrm{~cm}$ 以下の層は固結した槒層であった。從って有効 土層が浅く，園相は不良であった。

(3) 金武村の土辝は，赤黄㐌土に区分されているか，む しろ赤色土といった臣らがよいと思われた。国頭砂層 に由来するとはい光，砅が少なく，ち密度す深さ $45 \mathrm{~cm}$ まて20以下を示し，細根も哚くまで分布していた。従 って園相す極めて良好であった。

海成沖積層に由来する茶園は一力所の及調查したが, その結果は図 3 に示したと抢りである。

(1)大宜味の土摆は，表層土が淡黄褐色を呈しており， 褐色低地土に区分される。第2 層は赤黄色士，第3層 は赤色〜赤黄色土に相当すると思われた。松坂らによ れば，表層からの鉄の溶脱が認められている。すなわ ち軽いポドソリゼイションが進行していると指摘して いる。

\section{3-3 土猿の粒径組成}

層位別土壤の粒径組成を調ベた結果を示すと，表 20 と扣りである。これによると，粘板岩に由来する国頭郡 奥山一I，II扣よび名護市金川の3土噻は，表層から下 層まて比較的シルト含量が多く，上性は埴壤土一軽埴土 を示した。宜野座福山の土壤は，表層から下層まで粘土 含量が50\%以上を示し，きわめて重粘な土壌であった。

国頭砂層に属する 3 土壤の層位別粒径組成についてみ るとそれれぞれ異なった粒径組成を示していた。これら
のうち金武村の土壌は，第 2 痛以下に粘板岩に由来する 土壤の混入が多く，粘土含量が50\%以上で土性は重埴土 であった。

海成沖積盧に由来する大宜味の土壤は，粘土含量が 50 \%以下で土性は㪕埴土であった。

変成岩に由来する名護市の土壤は，粘土含量が $7.4 \%$ ときわめて少なく，粗砂の含量が $45.8 \%$ ときわ多い 砂壤土であった。

\section{3-4 土培の一般化学的性質}

土堷の一般化学的性質として土壌反心拈よび置換性塩

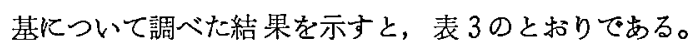
これによると,いずれの土境も強酸性を示し, 置換酸 度 $y_{1}$ b大きかった。 また，第 2 層の $y_{1}$ が第 1 層より大 きかった。これは本邦各地の茶園土壤調査結果にるみら れて拈り，アルミニウムの第 2 層への移行，集積による るのと推察される。

置換性塩舆についてみると，国頭郡奥山一I，名護市 金川，名護市呉我，大宜味津波拈よび名護市の土壌は， いずれる固換性石灰飽和度が $10 \%$ 以下で置換性石灰が不 足している。

置換性のカリの肥区度基準は，飽和度で 5〜10\%あれ ば十分であるとされているが，国頭郡奥山一I，名護市 金川於よび大宜味津波の土塨はやや不足していた。

冝換性マグネシウムも，飽和度で最低 596 が必要であ るが，名謢市金川，名謢市只我括よび国頭郡本部町の土 塨はいずれる5\%以下で，マグネシウムが不足してい た。

次に全窒装, 全炭素, リン酸吸収係数および有効態り ン酸含量を調べた結果を示すと，表 4 のとおりである。

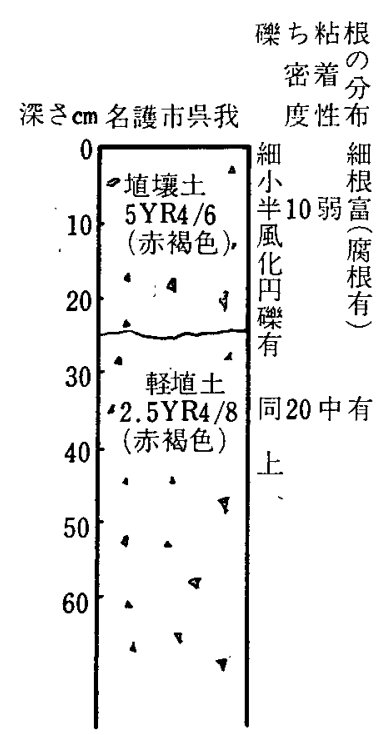

国頭碎層

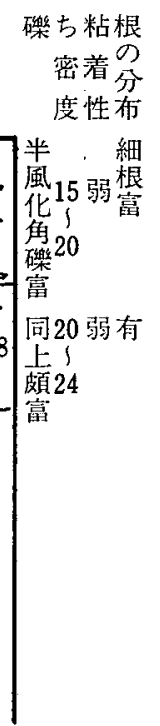

国頍磷層
国頭䂺層

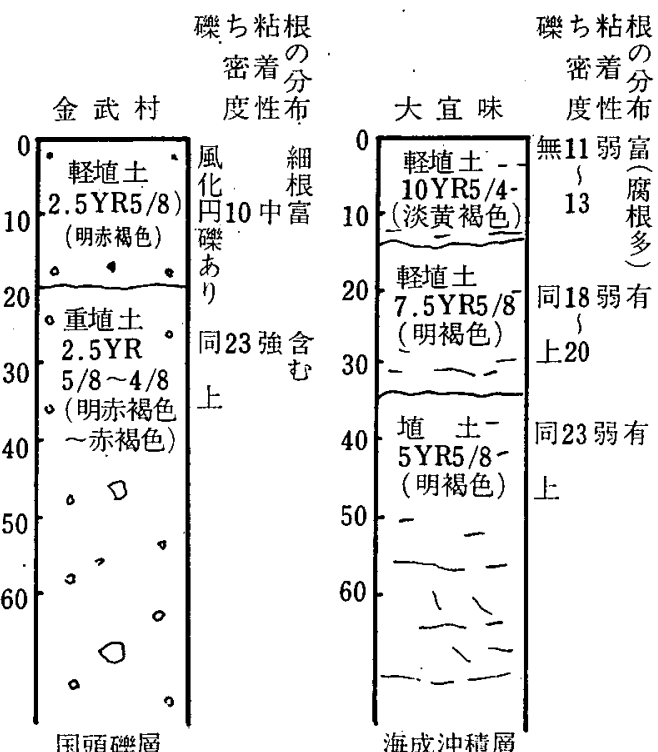

礫ち粘根 密着分 大宜味度性布

海成沖糐層

困 3 国頭啋層および海成沖積層に由来する茶園の土培断面調査結果 
表 2 土壤の粒径組成

\begin{tabular}{|c|c|c|c|c|c|c|c|c|c|}
\hline \multirow{2}{*}{ 地 } & \multirow{2}{*}{ 質 } & \multirow{2}{*}{ 地 } & \multirow{2}{*}{$\begin{array}{c}\text { 深 } \\
(\mathrm{cm})\end{array}$} & \multirow{2}{*}{ 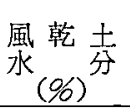 } & 粒 & 径 & \multicolumn{2}{|c|}{ 組 成 $(\%)$} & \multirow{2}{*}{ \pm} \\
\hline & & & & & 粗砂 & 細 & シルト & 粘 & \\
\hline \multirow{4}{*}{ 粘 } & \multirow{4}{*}{ 板 岩 } & 国頭郡奥山一Ｉ & $\begin{array}{r}0 \sim 15 \\
15 \sim 30\end{array}$ & $\begin{array}{l}5.0 \\
6.6\end{array}$ & $\begin{array}{r}21.2 \\
2.5 \\
\end{array}$ & $\begin{array}{l}27.0 \\
20.8 \\
\end{array}$ & $\begin{array}{l}31.6 \\
35.6 \\
\end{array}$ & $\begin{array}{l}20.2 \\
41.1\end{array}$ & $\begin{array}{l}\mathrm{CL} \\
\mathrm{LiC}\end{array}$ \\
\hline & & 同 上-II & $\begin{array}{l}0 \sim 15 \\
15 \sim 36 \\
36 \sim\end{array}$ & $\begin{array}{l}2.3 \\
2.1 \\
2.1\end{array}$ & $\begin{array}{l}17.9 \\
12.2 \\
25.5\end{array}$ & $\begin{array}{l}19.7 \\
18.2 \\
27.5\end{array}$ & $\begin{array}{l}36.6 \\
29.2 \\
30.3\end{array}$ & $\begin{array}{l}25.8 \\
30.4 \\
16.7\end{array}$ & $\begin{array}{l}\mathrm{LiC} \\
\mathrm{LiC} \\
\mathrm{CL}\end{array}$ \\
\hline & & 名誮市金川 & $\begin{array}{l}0 \sim 25 \\
25 \sim 47 \\
47 \sim\end{array}$ & $\begin{array}{l}6.5 \\
3.1 \\
5.6\end{array}$ & $\begin{array}{l}7.2 \\
5.8 \\
4.6\end{array}$ & $\begin{array}{l}18.2 \\
24.2 \\
27.1\end{array}$ & $\begin{array}{l}30.1 \\
37.3 \\
38.2\end{array}$ & $\begin{array}{l}44.5 \\
32.7 \\
30.1\end{array}$ & $\begin{array}{l}\mathrm{LiC} \\
\mathrm{LiC} \\
\mathrm{LiC}\end{array}$ \\
\hline & & 宜野座 福 山 & $\begin{array}{l}0 \sim 26 \\
26 \sim\end{array}$ & $\begin{array}{l}5.1 \\
4.6 \\
\end{array}$ & $\begin{array}{l}2.1 \\
0.9 \\
\end{array}$ & $\begin{array}{l}13.9 \\
11.4 \\
\end{array}$ & $\begin{array}{l}18.3 \\
18.7 \\
\end{array}$ & $\begin{array}{l}65.7 \\
69.0 \\
\end{array}$ & $\begin{array}{l}\mathrm{HC} \\
\mathrm{HC}\end{array}$ \\
\hline \multirow{3}{*}{ 国 } & \multirow{3}{*}{ 頁磼 層 } & 名護市呉我 & $\begin{array}{l}0 \sim 25 \\
25 \sim\end{array}$ & $\begin{array}{l}3.1 \\
3.4 \\
\end{array}$ & $\begin{array}{l}7.0 \\
4.7 \\
\end{array}$ & $\begin{array}{l}41.9 \\
36.3 \\
\end{array}$ & $\begin{array}{l}28.4 \\
24.0 \\
\end{array}$ & $\begin{array}{l}22.7 \\
35.0 \\
\end{array}$ & $\begin{array}{l}\mathrm{CL} \\
\mathrm{LiC} \\
\end{array}$ \\
\hline & & 国頭郡本部町 & $\begin{array}{l}0 \sim 20 \\
20 \sim\end{array}$ & $\begin{array}{l}4.2 \\
2.6\end{array}$ & $\begin{array}{l}9.1 \\
7.5 \\
\end{array}$ & $\begin{array}{l}23.5 \\
22.7\end{array}$ & $\begin{array}{l}50.3 \\
52.3 \\
\end{array}$ & $\begin{array}{l}17.1 \\
17.5\end{array}$ & $\begin{array}{l}\text { SiCL } \\
\text { SiCL }\end{array}$ \\
\hline & & 金 武 村 & $\begin{array}{r}0 \sim 20 \\
20 \sim 45 \\
\end{array}$ & $\begin{array}{l}4.5 \\
4.2 \\
\end{array}$ & $\begin{array}{l}9.5 \\
9.3 \\
\end{array}$ & $\begin{array}{l}27.1 \\
20.6 \\
\end{array}$ & $\begin{array}{l}22.0 \\
19.0 \\
\end{array}$ & $\begin{array}{l}41.4 \\
51.1\end{array}$ & $\begin{array}{l}\mathrm{LiC} \\
\mathrm{HC}\end{array}$ \\
\hline \multicolumn{2}{|c|}{ 海 成 沖 積 } & 大宜味津 波 & $\begin{array}{r}0 \sim 15 \\
15 \sim 35\end{array}$ & $\begin{array}{l}3.2 \\
4.1\end{array}$ & $\begin{array}{l}10.5 \\
11.9\end{array}$ & $\begin{array}{l}26.0 \\
23.6\end{array}$ & $\begin{array}{l}37.0 \\
25.6\end{array}$ & $\begin{array}{l}26.4 \\
38.9\end{array}$ & $\begin{array}{l}\mathrm{LiC} \\
\mathrm{LiC}\end{array}$ \\
\hline 変 & 成 岩 & 名 護 市 & $0 \sim 25$ & 2.2 & 45.8 & 26.4 & 20.4 & 7.4 & SL \\
\hline
\end{tabular}

表 3 土㴏の反応および置換性塩基（乾土中）

\begin{tabular}{|c|c|c|c|c|c|c|c|c|c|c|c|c|}
\hline \multirow[b]{2}{*}{ 地筫母材 } & \multirow{2}{*}{ 地 } & \multirow[b]{2}{*}{$\begin{array}{c}\text { 樑 さ } \\
(\mathrm{cm})\end{array}$} & \multicolumn{2}{|c|}{ pH } & \multirow{2}{*}{$\begin{array}{l}\text { 置 換 } \\
\text { 酸 } \\
\left.\left(\mathrm{y}^{1}\right)^{1}\right)\end{array}$} & \multirow{2}{*}{$\begin{array}{l}\text { 塩基置 } \\
\text { (me) } \\
\text { (me }\end{array}$} & \multicolumn{3}{|c|}{ 置換性塩基 (me) } & \multicolumn{3}{|c|}{ 置換性塩基飽和度 (\%) } \\
\hline & & & $\mathrm{H}_{2} \mathrm{O}$ & $\mathrm{KCl}$ & & & 石灰 & 力リ & $\begin{array}{l}\text { マグネ } \\
\text { シウム }\end{array}$ & 石灰 & 力y & $\begin{array}{l}\text { マグネ } \\
\text { シウム }\end{array}$ \\
\hline \multirow{10}{*}{ 粘 板 岩 } & \multirow{2}{*}{ 国頭郡奥山 - I } & $0 \sim 15$ & 3.40 & 3.00 & 22.2 & 26.7 & 1.97 & 1.07 & 2.68 & 7.38 & 4.01 & 10.04 \\
\hline & & $15 \sim 30$ & 3.80 & 3.30 & 34.0 & 13.9 & 0.65 & 0.61 & 0.36 & 4.68 & 4.39 & 2.59 \\
\hline & \multirow{3}{*}{ 同 上一II } & $0 \sim 15$ & 4.20 & 3.60 & 2.8 & 9.8 & 3.50 & 0.93 & 1.07 & 35.71 & 9.49 & 10.92 \\
\hline & & $15 \sim 36$ & 3.70 & 3.10 & 32.4 & 7.2 & 2.25 & 0.46 & 0.29 & 31.25 & 6.39 & 4.03 \\
\hline & & $36 \sim$ & 3.90 & 3.50 & 18.9 & 4.6 & 0.60 & 0.23 & $\operatorname{tr}$. & 13.00 & 5.00 & $\operatorname{tr}$. \\
\hline & \multirow{3}{*}{ 名護市金川 } & $0 \sim 25$ & 3.50 & 3.00 & 20.5 & 29.7 & 1.55 & 0.64 & 0.43 & 5.22 & 2.15 & 1.45 \\
\hline & & $25 \sim 47$ & 3.70 & 3.00 & 20.8 & 20.0 & 1.95 & 1.20 & 0.85 & 9.75 & 6.00 & 4.25 \\
\hline & & $47 \sim$ & 3.90 & 3.48 & 38.8 & 15.1 & 0.77 & 0.56 & 0.38 & 5.10 & 3.71 & 2.52 \\
\hline & \multirow{2}{*}{ 宜野座福山 } & $0 \sim 26$ & 3.90 & 3.39 & 18.0 & 15.3 & 3.50 & 1.69 & 1.32 & 22.88 & 11.05 & 8.63 \\
\hline & & $26 \sim$ & 4.20 & 3.49 & 26.4 & 10.7 & 1.70 & 0.78 & 0.51 & 15.88 & 7.29 & 4.77 \\
\hline \multirow{6}{*}{ 国頭留 } & \multirow{2}{*}{ 名護市点我 } & $0 \sim 25$ & 2.90 & 2.50 & 18.4 & 21.6 & 0.55 & 1.44 & 0.26 & 2.55 & 6.66 & 1.20 \\
\hline & & $25 \sim$ & 3.20 & 2.70 & 43.2 & 15.1 & 0.37 & 0.66 & 0.27 & 2.45 & 4.37 & 1.70 \\
\hline & \multirow{2}{*}{ 国頭郡本部町 } & $0 \sim 20$ & 3.90 & 3.45 & 14.6 & 26.0 & 4.70 & 2.26 & 0.34 & 18.08 & 8.69 & 1.31 \\
\hline & & $20 \sim$ & 3.90 & 2.85 & 20.6 & 15.1 & 1.87 & 0.20 & 0.24 & 12.38 & 1.32 & 1.59 \\
\hline & \multirow{2}{*}{ 金 武 村 } & $0 \sim 20$ & 4.30 & 3.78 & 7.2 & 14.9 & 4.00 & 1.39 & 1.32 & 26.85 & 9.33 & 8.86 \\
\hline & & $20 \sim 45$ & 4.10 & 3.36 & 24.6 & 9.5 & 2.20 & 0.49 & 0.47 & 23.16 & 5.16 & 4.95 \\
\hline \multirow{2}{*}{ 海成沖積層 } & \multirow{2}{*}{ 大宜味津波 } & $0 \sim 15$ & 4.50 & 3.45 & 9.8 & 16.3 & 0.45 & 0.52 & 1.45 & 2.76 & 3.19 & 8.89 \\
\hline & & $15 \sim 35$ & 4.30 & 3.55 & 37.0 & 9.3 & 0.37 & 0.26 & tr. & 3.98 & 2.80 & tr. \\
\hline 変 成 岩 & 名 護 市 & $0 \sim 25$ & 3.70 & 3.10 & 7.6 & 13.9 & 1.12 & 1.46 & 0.94 & 8.06 & 10.50 & 6.76 \\
\hline
\end{tabular}


第 54 号 $\left(\begin{array}{llll}1 & 9 & 8 & 1\end{array}\right)$

表 4 土培の全窒素, 全炭素括よびリン酸吸収係数（乾土中）

\begin{tabular}{|c|c|c|c|c|c|c|c|c|}
\hline 顊 & 地 & $\begin{array}{l}\text { 深 } \\
(\mathrm{cm})\end{array}$ & $\begin{array}{l}\text { 全㗌素 } \\
(\%)\end{array}$ & $\begin{array}{l}\text { 全炭素 } \\
(\%)\end{array}$ & $\mathrm{C} / \mathrm{N}$ & $\begin{array}{c}\text { 笱 } \\
(\%)\end{array}$ & 贤收係数 & $\begin{array}{r}\text { 有効態 } \\
\text { 1)酸 } \\
(\mathrm{mg} \%)\end{array}$ \\
\hline \multirow{10}{*}{ 板＼cjkstart岩 } & \multirow{2}{*}{ 国頭郡奥山一I } & $0 \sim 15$ & 0.554 & 4.08 & 7.36 & 7.03 & 400 & 40.5 \\
\hline & & $15 \sim 30$ & 0.011 & 0.66 & 60.00 & 1.14 & 760 & 0.8 \\
\hline & \multirow{3}{*}{ 同 上一II } & $0 \sim 15$ & 0.299 & 1.77 & 5.92 & 3.04 & 440 & 36.5 \\
\hline & & $15 \sim 36$ & 0.008 & 0.27 & 33.75 & 0.47 & 580 & 1.8 \\
\hline & & $36 \sim$ & 0.003 & 0.12 & 40.00 & 0.21 & 460 & 0.6 \\
\hline & \multirow{3}{*}{ 名護市金川 } & $0 \sim 25$ & 0.582 & 4.50 & 7.73 & 7.76 & 880 & 29.0 \\
\hline & & $25 \sim 47$ & 0.381 & 2.22 & 5.83 & 3.83 & 560 & 46.0 \\
\hline & & $47 \sim$ & - & 0.39 & 一 & 0.67 & 800 & 0.6 \\
\hline & \multirow[b]{2}{*}{ 宜野座福山 } & $0 \sim 26$ & 0.274 & 1.50 & 5.47 & 2.59 & 760 & 19.6 \\
\hline & & $26 \sim$ & - & 0.39 & - & 0.67 & 940 & 2.6 \\
\hline \multirow{6}{*}{ 頭 碗 層 } & \multirow{2}{*}{ 名護市咺我 } & $0 \sim 25$ & 0.428 & 3.09 & 7.22 & 5.33 & 340 & 27.5 \\
\hline & & $25 \sim$ & - & 0.93 & - & 1.60 & 520 & 10.1 \\
\hline & \multirow{2}{*}{ 国頭郡本部町 } & $0 \sim 20$ & 1.053 & 7.68 & 7.29 & 13.24 & 260 & 99.4 \\
\hline & & $20 \sim$ & 0.434 & 3.48 & 8.02 & 5.99 & 380 & 14.6 \\
\hline & \multirow{2}{*}{ 金 武 村 } & $0 \sim 20$ & 0.442 & 2.37 & 5.36 & 4.09 & 880 & 40.0 \\
\hline & & $20 \sim 45$ & - & 0.30 & - & 0.52 & 860 & 0.8 \\
\hline \multirow[b]{2}{*}{ 成 沖 積 } & \multirow{2}{*}{ 大宜味津波 } & $0 \sim 15$ & 0.492 & 4.32 & 8.82 & 7.45 & 620 & 3.3 \\
\hline & & $15 \sim 35$ & - & 0.78 & - & 1.34 & 760 & 1.2 \\
\hline 変 成 岩 & 名 護 市 & $0 \sim 25$ & 0.420 & 2.52 & 6.00 & 4.34 & 240 & 14.0 \\
\hline
\end{tabular}

これKよると，一般的ではあるが，各土裹とも腐植含 量が少なかった。リン酸吸収係数はいずれの土㙴す小さ かった。有効態リン酸含量は表層土で 30〜 $50 \mathrm{mg} \%\left(\mathrm{P}_{2}\right.$ $\mathrm{O}_{5}$ として) あればよいが，宜野座福山，大宜味津波拉上 び名護支場では不足していた。

以上, 沖縄本島の土塨の概要 抢よび一般理化学的性質 について調べた結果について述べたが，沖縄本島の茶園 は大部分が絬板岩と国頭㟫層に由来する土境地帯に分布 しておりこれらの土壃はいずれる強酸栍を示してい た。物理的性質では，下層土が重粘でち密度の高い土壤 が多いことから下層土の改良が今後の課題と思われた。 しかし, 排水促進対策が必要と思われる茶園は少なかっ た。

今後，国頭啋層炕由来するパイナップル園などを茶園 に転換する場合，土猿の流亡，造園地の崩かいなどにつ いて十分配慮をしなければならない。また，地力の増強 には適切な酸度矯正と有機物資材の投入が必要と思われ た。

本調查を行う火当たり，格別なる御協力，御支援を睗 った沖縄県農試名護支場の仲間 銀一氏，富里 邦氏をは じめ，関係各位に樑甚なる謝意を表します。
4 要約

沖縄本島の茶園土壌は, 粘板岩, 国頭磉層, 变成岩お よび海成沖皘層に由来する赤黄色土であった。

国頭檫層に由来する土㙵地帯では，ガリエロージョン や土地崩かいがみられた。

断面調查によれば，いずれも第 2 層のち密度が 20 以上 を示していた。細根は第 1 層に多く，第 2 層に少なかっ た。

国頭礫層に由来する茶園土壤の土性は， $\mathrm{SiC} \sim \mathrm{CL} て ゙$ あった。沖積層では $\mathrm{LiC}$, 粘板岩では $\mathrm{LiC} \sim \mathrm{HC}$, 変成 岩ではSLであった。

土境の反応はいずれる強酸性を示した。臣とんどが $\mathrm{pH}$ $\left(\mathrm{H}_{2} \mathrm{O}\right) 4.5$ 以下で，2.9を示字のもあった。 有機物含量はいずれの土壌も少なかった。

粘板岩に由来する茶園土壤で，置換性マグネシウム が多かったが，他の土壤では少なかった。また，置換性 カリウムは一般に多かった。

リン酸吸収係数はいずれの土壤も小さく，有効態リン 酸 (トルオーグ法) は $50 \mathrm{mg} \%$ 以上を示するのと, 逆に 不足しているすのとがあった。 


\section{5 引用文 献}

1）松坂泰明, 音羽道三, 山田 裕, 浜崎忠雄: 農技研 報告， B22，305 404 (1971).

2）小林 嵩, 品川昭夫：鹿大農学術報告, No. 16,11 $\sim 15$ (1966).

3）茶関係専門別総括検討会議育種部会: 茶研報, No. 51,63 (1980).

4）河合物吾: 茶試研報; No. 2，1～234 (1965).

5）池兮谷蜸次郎：茶試研報，No. 1，144２27 (1962).

6）池ケ谷賢次郎：茶試研報, No.10, 133 208 (1974).

\section{Summary}

The tea soils in Okinawa Island were red yellow soils derived from Slate, Kunigami Gravel, Metamorphic rock and Coastal plain.

Gully erosion and landslide were observed at Kunigami gravel soil area.

The second layers of every tea soil were very compact, the index of soil strength of those soils was over 20 , and the slender root of tea plant in the 2 nd layer was very little.

Each soil texture derived from Kunigami gravel, Coastalplain, Slate and Metamorphic rocks tea soils was that of $\mathrm{SiCL} \sim \mathrm{CL}, \mathrm{LiC}, \mathrm{LiC} \sim \mathrm{HC}$ and $\mathrm{SL}$ respectively.

Every tea soil indicated strong acidity, that is, $\mathrm{pH}\left(\mathrm{H}_{2} \mathrm{O}\right)$ values of most of the soils were under 4.5 and some one was 2.9 .

The content of soil organic matter in every soil was very little.

The exchangeable magnesium content of the tea soil derived from Slate was high and that of soils derived from the other origin was low, and exchangeable potassium content in evrey soil was higher than the best condition of potassium fertility of tea soil.

Phosphorus absorption coefficients in every tea soil were low, and contents of available phosphorus (Truog) were various in every tea soil and one of them was $50 \mathrm{mg} \%\left(\mathrm{P}_{2} \mathrm{O}_{5}\right)$ and the others were very little.

(Jan. 17, 1981) 